\title{
Factors affecting the occurrence of bark- and wood-boring beetles on Scots pine logging residues from pre-commercial thinning
}

\section{Jiř́í Foit}

Foit, J. 2015: Factors affecting the occurrence of bark- and wood-boring beetles on Scots pine logging residues from pre-commercial thinning. - Entomol. Fennica 26: 74-87.

A total of 480 Scots pine (Pinus sylvestris L.) trees felled during pre-commercial thinning in a single stand in the Drahanská Highlands in the Czech Republic were examined for the occurrence of bark- and wood-boring beetles. Thinning was performed on different dates during 2006 and 2007 (February, May, August and November). Half of the felled trees were cut into $1 \mathrm{~m}$-long sections, and the rest were left whole. The fauna inhabiting the logging residues were investigated by peeling off the bark of the felled trees during the first six months of the vegetative period following felling. The studied logging residues hosted species-rich assemblages of bark- and wood-boring beetles ( 28 species identified), including numerous populations of several pest species (Pityogenes chalcographus, Tomicus minor and Tomicus piniperda). The occurrence of species was significantly affected mainly by the part of the tree and its diameter and bark thickness and by the felling date and post-felling cutting of the trees.

J. Foit, Department of Forest Protection and Wildlife Management, Faculty of Forestry and Wood Technology, Mendel University in Brno, Zemědělská 3, 613 00 Brno, Czech Republic; E-mail:pink.foit@email.cz

Received 26 June 2014, accepted 3 December 2014

\section{Introduction}

Substantial quantities of logging residues (LR) are produced every year through forest management. These LR may serve as a substrate for the development of certain forest bark- and woodboring pests (especially bark beetles), and in certain circumstances, they can facilitate pest multiplication and outbreaks (Schroeder 2008). Various strategies for the removal of LR (e.g., hauling, burning, chipping) are often recommended to prevent the multiplication of pests (DeGomez et al. 2008). Extensive removal of LR might arise from the current tendency to harvest biomass as a renewable energy source. However, LR form a substantial portion of the dead wood present in managed forests, and their removal can lead to the extinction of scarce saproxylic species and a loss of overall diversity (Siitonen 2001, Jonsell et al. 2007, Maňák 2007, Jonsell 2008, Victorsson \& Jonsell 2013). Hence, many studies (Kaila et al. 1997, Jonsell et al. 2004, Lindhe \& Lindelöw 2004) have encouraged the deliberate retention of certain parts of trees (e.g., high stumps, snags, tops or branches) in managed forests to increase the diversity of saproxylic insects.

There are a number of studies focusing on LR as a substrate for pest development (Six et al. 
2002, Hedgren et al. 2003, Johansson et al. 2006, Kula \& Kajfosz 2006, 2007, Zabecki \& Kacprzyk 2007, Foit 2012b, Kacprzyk 2012), in addition to many studies addressing the conservational value of LR (e.g., Schiegg 2001, Lindhe \& Lindelöw 2004, Jonsell et al. 2007, Maňák 2007, Jonsell 2008, Brin et al. 2011, Lassauce et al. 2012). The occurrence of saproxylic beetles on LR or dead wood is affected by an array of substrate characteristics, including stand conditions and the position of dead wood within the stand (Peltonen \& Heliövaara 1999, Sverdrup-Thygeson \& Ims 2002, Jonsell \& Weslien 2003, McGeoch et al. 2007); the total volume, connectivity and continuity of dead wood (Schiegg 2000, Similä et al. 2003, Vanderwel et al. 2006); bark thickness (Zhang et al. 1993, Foit 2010); substrate diameter (Schiegg 2001, Lindhe \& Lindelöw 2004, Lindhe et al. 2005, Jonsell et al. 2007, Maňák 2007, Jonsell 2008, Foit 2010); sun exposure (Jonsell et al. 2004, Lindhe \& Lindelöw 2004, Lindhe et al. 2005, Jonsell 2008); moisture (Wallace 1953, Larkin \& Elbourn 1964); the stage of decomposition (Wallace 1953, Vanderwel et al. 2006, Jonsell 2008); and the presence of various other organisms (Jonsell et al. 2005, Abrahamsson et al. 2008, Weslien et al. 2011).

Given these associations, it is not surprising that saproxylic beetles colonising LR are influenced by the date of LR production (felling date) (Kula \& Kajfosz 2006, 2007, Foit 2012a, b) and deposition (Six et al. 2002, Foit 2011, Kacprzyk 2012). The effects of other management strategies, such as the post-felling cutting of LR into shorter sections, might also be substantial but have not yet been documented. Most of the studies addressing LR have been conducted on LR generated from the final felling or thinning in older stands, where only tree tops, branches and stumps remain. However, only few studies (Kula $\&$ Kajfosz, 2006, 2007) have specifically examined LR arising from pre-commercial thinning, where whole trees remain in the stand. The fauna of LR generated by pre-commercial thinning might be very specific, comprising species associated with thick bark and the basal part of the trunk that do not find suitable habitats in other types of LR.

The goal of this study was to investigate which bark- and wood-boring beetle (BWBB) species develop and multiply on Scots pine (Pinus sylvestris L.) LR generated through precommercial thinning and to assess the effects of various habitat variables, including the diameter and bark thickness of the LR fragment, the felling date, and the post-felling cutting of the trees into sections, on the occurrence of the recorded species.

\section{Material and methods}

\subsection{Study site}

The study was conducted in the southern part of the Drahanská Highlands in the Czech Republic. The climate of the study area is characterised by mean annual temperatures of $8.4-8.5^{\circ} \mathrm{C}$ and an average annual rainfall of approximately 580 $590 \mathrm{~mm}$. The forests in the study area have traditionally been managed under a clear-cutting system with prevalent artificial regeneration.

The study stand $\left(49^{\circ} 15^{\prime} 38^{\prime \prime} \mathrm{N} / 16^{\circ} 36^{\prime} 52^{\prime \prime} \mathrm{E}\right)$ had an area of 1.4 ha and was situated between 350 and 385 m elevation on an east- to southeastfacing slope with a gradient of approximately 10 $15 \%$. This even-aged stand was approximately 17 years old, and its main canopy was composed primarily of Scots pines (70\%), though sessile oak (Quercus petraea (Matt.) Liebl.) (8\%), European larch (Larix decidua Mill.) (8\%), silver birch (Betula pendula Roth) (6\%), small-leaved lime (Tilia cordata) Mill. (4\%) and European hornbeam (Carpinus betulus L.) (2\%) were also present.

\subsection{Sampling}

The studied stand was divided into four parts, each with the same area ( $0.35 \mathrm{ha})$, and experimental felling was conducted on a different date in each part. The dates on which felling occurred were 11.IX.2006, 10.II.2007, 10.V.2007 and 12.VIII.2007. During each felling event, 170 (or slightly more) pines were felled (stand density was decreased from 2,200 trees/ha to $1,700 /$ ha). Half of the felled trees were subsequently cut into $1 \mathrm{~m}$-long sections, and the remaining trees were left whole (uncut). The total height of the felled 
Table 1. Metric variables (diameter and bark thickness) of the distinguished tree parts represented by the mean \pm standard deviation (range).

\begin{tabular}{lcll}
\hline Tree part & $\begin{array}{c}\text { No. of trees } \\
\text { with presence } \\
\text { of tree part }\end{array}$ & $\begin{array}{l}\text { Diameter } \\
(\mathrm{cm})\end{array}$ & $\begin{array}{l}\text { Bark thickness } \\
(\mathrm{mm})\end{array}$ \\
\hline 1. trunk section & 480 & $12.2 \pm 2.6(7.0-18.0)$ & $10.4 \pm 2.7(4.0-20.0)$ \\
2. trunk section & 480 & $11.2 \pm 2.6(6.0-17.0)$ & $6.0 \pm 2.2(2.0-15.0)$ \\
3. trunk section & 480 & $9.2 \pm 2.4(4.0-14.5)$ & $3.7 \pm 1.8(1.0-13.0)$ \\
4. trunk section & 480 & $8.2 \pm 2.3(3.0-13.0)$ & $2.4 \pm 1.3(1.0-9.0)$ \\
5. trunk section & 480 & $7.2 \pm 2.1(3.0-12.0)$ & $1.6 \pm 0.8(1.0-6.0)$ \\
6. trunk section & 480 & $6.2 \pm 2.0(2.0-10.0)$ & $1.3 \pm 0.5(1.0-4.0)$ \\
7. trunk section & 480 & $5.2 \pm 1.9(1.5-9.0)$ & $1.1 \pm 0.3(1.0-3.0)$ \\
8. trunk section & 472 & $4.3 \pm 1.7(1.0-8.0)$ & $1.0 \pm 0.2(1.0-2.0)$ \\
9. trunk section & 463 & $3.5 \pm 1.5(1.5-7.5)$ & $1.0 \pm 0.2(1.0-2.0)$ \\
10. trunk section & 438 & $3.5 \pm 1.4(1.0-7.0)$ & $1.0 \pm 0.2(1.0-2.0)$ \\
11. trunk section & 357 & $3.0 \pm 1.1(1.0-6.0)$ & $1.0 \pm 0.1(1.0-2.0)$ \\
12. trunk section & 279 & $1.9 \pm 0.6(1.0-3.0)$ & $1.0 \pm 0.0(1.0-1.0)$ \\
13. trunk section & 141 & $1.8 \pm 0.4(1.0-2.0)$ & $1.0 \pm 0.0(1.0-1.0)$ \\
14. trunk section & 42 & $1.8 \pm 0.8(1.0-2.0)$ & $1.0 \pm 0.0(1.0-1.0)$ \\
Branches thicker than $1 \mathrm{~cm}$ & 480 & $2.0^{*}$ & $1.0^{*}$ \\
Branches thinner than $1 \mathrm{~cm}$ & 480 & $0.8^{*}$ & $1.0^{*}$ \\
\hline
\end{tabular}

* Because all of the branches were not measured, the standard deviation and range could not be calculated (see Methods).

trees was 7-14 $\mathrm{m}$, and their diameter at breast height was 6-17 cm.

Sampling began 14 days after felling and was repeated every 14 days during the vegetative period ( $23^{\text {rd }}$ April through $10^{\text {th }}$ October) until 12 repetitions had been performed in each part of the stand with a different felling date. During each sampling event, five whole and five cut trees were sampled from each part of the stand felled on the different dates. Thus, 480 trees ( 60 whole and 60 cut trees in each of 4 parts of the stand) were sampled in total. The trunks of the uncut trees were divided into $1-\mathrm{m}$-long sections, and 7 to 14 trunk sections (according to the tree height) were distinguished on each sampled tree (cut and uncut); all of these trunk sections were analysed. The upper (upward-facing) and lower (groundfacing) halves (sides) of the trunk section surfaces were sampled separately. Additionally, one upward-facing branch was sampled from each trunk section that had living branches at the time of felling, and sections of the branches that were thicker or thinner than $1 \mathrm{~cm}$ were sampled separately. Thus, 9 to 16 tree parts ( 7 to 14 trunk sections and 2 categories of sampled branches) were distinguished on specific sampled trees (Table 1). The diameter and bark thickness were recorded in the middle of each trunk section, although constant average values of these variables were obtained by measuring two branches on each 10th analysed tree and used for the branch categories (Table 1). Furthermore, contact between the trunk and ground was recorded for each trunk section, and the section was classified as "air" or "ground" if less or more than $1 / 3$ of its length was touching the ground, respectively. Each analysed tree part was entirely debarked, and all of the BWBB (phloemo-, xylo- and xylomycetophagous) species present were identified based on the gallery characteristics or the morphological traits of imagos or larvae (Švácha \& Danilevsky 1986, 1987, 1988, Bílý 1989, Bense 1995, Pfeffer 1995). Finally, the gallery coverage of each species was evaluated on a semi-logarithmic, six-degree scale according to the visually estimated percentage of the area exploited by the species within the sample mantle $(<1 \%, 1-5 \%$, $6-25 \%, 26-50 \%, 51-75 \%$ and $>75 \%$, see BraunBlanquet 1964).

\subsection{Statistical analyses}

The frequency of the occurrence of each species was expressed as the proportion of samples occu- 
Fig. 1. Frequencies of occurrence of the recorded species. *Includes two species: Pogonocherus fasciculatus (De Geer) and Pogonocherus decoratus Fairmaire; **Includes two species: Magdalis frontalis (Gyllenhal) and Magdalis rufa Germar.

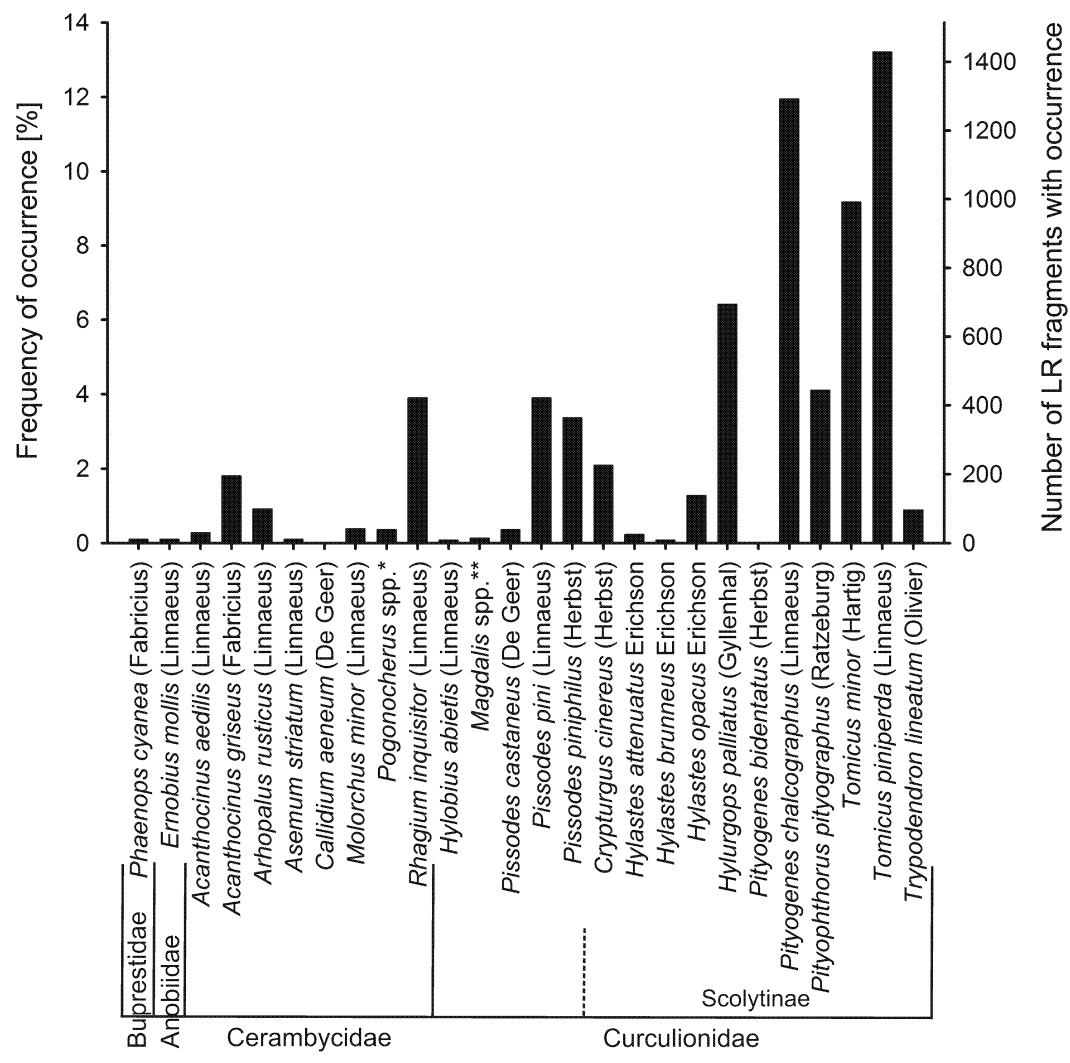

pied. In the statistical analysis, the abovementioned six-point scale of gallery coverage was represented by the mean values of the percentage intervals: $0.5 \%, 3 \%, 15.5 \%, 38 \%, 63 \%$ and $88 \%$. A canonical correspondence analysis (CCA) was used to assess the effects of the studied habitat variables on the species composition of the beetle assemblages. A CCA does not require normally distributed data, is not affected by the correlation of habitat factors and assumes unimodal models for the relationships between the responses of each species to the habitat variables. This approach is appropriate for this data set because a preliminarily detrended correspondence analysis showed long gradient lengths ( $>3$ SD) (ter Braak 1986, 1987). In the CCA, the Monte Carlo permutation test (Manly 2001), with 999 permutations, was used to compute the significance of the relationships between the species responses and habitat factors. When appropriate (i.e., to test for the significance of the tree parts, diameter and bark thickness), Monte Carlo permutation tests were restricted to permutations within blocks referring to particular trees. All of these analyses were performed in CANOCO for Windows (ter Braak 1987). All of the recorded species were included in the analyses; however, to avoid an undesirably high influence of species with low frequency caused by the standardisation by species, which is implicit in unimodal methods, rare species were down-weighted as a separate step of the analyses in CANOCO.

Because of the non-normal distribution of the data in the gallery coverage of particular species (tested by Shapiro-Wilk tests) that could not be corrected by data transformation, nonparametric statistics were used for further analyses (Hollander \& Wolfe 1999). To illustrate the strength of association among particular species with the tree parts and their metric variables, Spearman's correlation indices were calculated with the tree identity treated as a covariable, and its effect was removed from the dataset. This calculation was performed by fitting a Poisson generalised linear models (GLM) with a logarithmic link function (Dobson \& Barnett 2008) for each tested species 
Table 2. Canonical correspondence analysis - results of the Monte Carlo permutation tests for the significance of the studied habitat variables for species composition of bark- and wood-boring beetle assemblages. The percentage of the variance in the species gallery coverage explained by the studied factors is included. Values in parentheses show the results that considered additional covariables.

\begin{tabular}{|c|c|c|c|}
\hline Variable & $\begin{array}{l}\mathrm{F} \\
\mathrm{P} \\
(\%)\end{array}$ & Covariables & Additional covariables \\
\hline Tree identity & $\begin{array}{l}4.8 \\
0.001 \\
24.3\end{array}$ & - & - \\
\hline Tree part & $\begin{array}{l}11.0(8.4) \\
0.001(0.001) \\
7.1(5.5)\end{array}$ & $\begin{array}{l}\text { Tree identity, } \\
\text { sampling date }\end{array}$ & $\begin{array}{l}\text { Felling date, } \\
\text { post-felling cutting, } \\
\text { contact of LR with ground }\end{array}$ \\
\hline Diameter & $\begin{array}{l}90.3(49.5) \\
0.001(0.001) \\
4.0(2.6)\end{array}$ & $\begin{array}{l}\text { Tree identity, } \\
\text { sampling date }\end{array}$ & $\begin{array}{l}\text { Felling date, } \\
\text { post-felling cutting, } \\
\text { contact of LR with ground }\end{array}$ \\
\hline Bark thickness & $\begin{array}{l}67.5(31.9) \\
0.001(0.001) \\
3.1(1.4)\end{array}$ & $\begin{array}{l}\text { Tree identity, } \\
\text { sampling date }\end{array}$ & $\begin{array}{l}\text { Felling date, } \\
\text { post-felling cutting, } \\
\text { contact of LR with ground }\end{array}$ \\
\hline $\begin{array}{l}\text { Diameter and } \\
\text { bark thickness }\end{array}$ & $\begin{array}{l}52.9(34.5) \\
0.002(0.002) \\
4.7(3.1)\end{array}$ & $\begin{array}{l}\text { Tree identity, } \\
\text { sampling date }\end{array}$ & $\begin{array}{l}\text { Felling date, } \\
\text { post-felling cutting, } \\
\text { contact of LR with ground }\end{array}$ \\
\hline Felling date & $\begin{array}{l}21.9(17.0) \\
0.001(0.001) \\
3.7(2.6)\end{array}$ & Sampling date & $\begin{array}{l}\text { Tree part, diameter, bark } \\
\text { thickness, post-fell. cutting, } \\
\text { contact of LR with ground }\end{array}$ \\
\hline $\begin{array}{l}\text { Post-felling cutting } \\
\text { (whole/cut) }\end{array}$ & $\begin{array}{l}20.2(22.6) \\
0.003(0.001) \\
1.2(1.1)\end{array}$ & Sampling date & $\begin{array}{l}\text { Felling date, tree part, } \\
\text { diameter, bark thickness, } \\
\text { contact of LR with ground }\end{array}$ \\
\hline $\begin{array}{l}\text { Orientation of LR surface } \\
\text { towards ground } \\
\text { (upper/lower side) }\end{array}$ & $\begin{array}{l}6.3(5.9) \\
0.003(0.001) \\
0.3(0.3)\end{array}$ & $\begin{array}{l}\text { Tree identity, } \\
\text { tree part, } \\
\text { sampling date }\end{array}$ & $\begin{array}{l}\text { Felling date, diameter, bark } \\
\text { thickness, post-fell. cutting, } \\
\text { contact of LR with ground }\end{array}$ \\
\hline $\begin{array}{l}\text { Contact of LR } \\
\text { with ground } \\
\text { (air/ground) }\end{array}$ & $\begin{array}{l}3.7(3.4) \\
0.001(0.001) \\
0.3(0.3)\end{array}$ & $\begin{array}{l}\text { Tree identity, } \\
\text { tree part, } \\
\text { sampling date }\end{array}$ & $\begin{array}{l}\text { Felling date, diameter, } \\
\text { bark thickness, } \\
\text { post-felling cutting }\end{array}$ \\
\hline Sampling date & $\begin{array}{l}16.9 \\
0.001 \\
0.1\end{array}$ & - & - \\
\hline $\begin{array}{l}\text { All variables (except } \\
\text { tree identity) }\end{array}$ & $\begin{array}{l}12.9 \\
0.001 \\
16.6\end{array}$ & - & - \\
\hline
\end{tabular}

using tree identity as a predictor. The residuals associated with these models were then extracted, and the correlation indices were calculated using the residuals. The statistical significance of the differences in the gallery coverage of particular species on the LR with different (categorical) characteristics was tested using Kruskal-Wallis tests or Mann-Whitney U tests according to the number of groups to be compared. If significant differences were found by the Kruskal-Wallis tests, then the Mann-Whitney U tests with critical p-values that were decreased by Bonferroni adjustment (i.e., critical $P=0.008$ for the comparison of four different felling dates) were used to identify the pairs of datasets with significant differences. To test the effect of contact of LR with the ground, only the data for three basal trunk sections were considered because these tree parts without branches exhibited contact with the ground at a greater frequency. All of these calcu- 
lations were performed in Statistica 10.0 (StatSoft 2013).

\section{Results}

Among the 28 collected species of BWBB (Fig. $1)$, the family Curculionidae (17 species) was the most abundant. Most of the identified curculionids (11 species) were bark beetles (Scolytinae), and Tomicus piniperda (Linnaeus) and Pityogenes chalcographus (Linnaeus) were encountered most frequently (Fig. 1).

All of the studied habitat variables were significantly associated with the species composition of the BWBB assemblages and were able to explain $16.6 \%$ of the observed variability in the species' gallery coverage (Table 2, Fig. 2). The tree parts and metric variables were the most significant variables affecting the species composition of the BWBB assemblages. The felling date also had a comparably strong impact. The postfelling cutting of the trees affected the composition of the BWBB assemblages to a much lesser degree, although it was still considerable. In contrast, the effects of the orientation of the LR surface with respect to the ground and contact of the LR fragments with the ground were negligible although still statistically significant.

Particular species were associated with certain tree parts and their metric variables (Table 3, Fig. 2), and many of these associations were statistically significant. Among the species found on at least 100 LR fragments, Arhopalus rusticus (Linnaeus), Rhagium inquisitor (Linnaeus), Tomicus minor (Hartig) and Trypodendron lineatum (Olivier) exhibited the strongest associations with the tree parts (Table 3 ). The remaining species were more closely associated with the metric variables of the tree parts, and the following six species exhibited stronger associations with diameter: Acanthocinus griseus (Fabricius), Pissodes pini (Linnaeus), Crypturgus cinereus (Herbst), Hylastes opacus Erichson, Hylurgops palliatus (Gyllenhal) and Pityophthorus pityographus (Ratzeburg); however, the following six species exhibited stronger associations with bark thickness: A. rusticus, $R$. inquisitor, $P$. chalcographus, T. minor, T. piniperda and T. lineatum.

The felling date significantly affected the

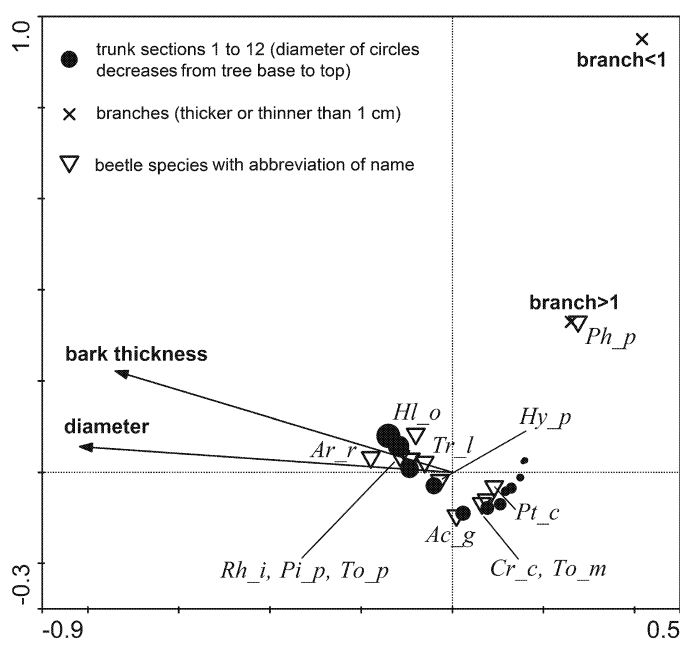

Fig. 2. Canonical correspondence analysis - associations of the tree parts and their basic variables with the species composition of bark- and wood-boring beetle assemblages (covariables: tree identity and sampling date; sum of eigenvalues of first and second axes $=1.653$, sum of all eigenvalues $=11.543, F=90.3$, $P=0.001)$. Species are denoted with the following abbreviations: Ac $g$ (Acanthocinus griseus), $A r r$ (Arhopalus rusticus), $\mathrm{Cr}$ _c (Crypturgus cinereus), HI_o (Hylastes opacus), Hy_p (Hylurgops palliatus), Pi p (Pissodes pini), Ph_p (Pityophthorus pityographus), Pt_c (Pityogenes chalcographus), Rh_i (Rhagium inquisitor), To_m (Tomicus minor), To_p (Tomicus piniperda) and Tr_I (Trypodendron lineatum). Only the species recorded on at least 100 LR fragments are shown.

overall species composition of the BWBB assemblages developing on the studied trees (Table 2). The gallery coverage of all species that were present on at least 100 LR fragments differed significantly between different felling dates (Table 4, Fig. 3a). Trees felled in November and February were regularly colonised by a majority of the species, with $R$. inquisitor, $H$. palliatus, $T$. piniperda and $T$. lineatum showing the highest frequency of occurrence on the trees from November and $C$. cinereus, $P$. chalcographus and $T$. minor being the most frequent on trees from February. Two species that avoided the colonisation of LR from November and/or February were $A$. rusticus and T. lineatum (avoided LR from February). While a few species (A. griseus, $A$. rusticus and $P$. pini) displayed the highest frequency of occurrence on trees felled in May, more species avoided these 
Table 3. Spearman correlation indices among the tree parts and their metric variables and among the tree parts, their metric variables and gallery coverage of each species. The effect of tree identity was removed from the data $(n=10,810)$ for the gallery coverage prior to calculating the indices by extracting the residuals from the fitted generalised linear model for each species using the tree identity as the predictor (see Methods). Only the species recorded for at least 100 logging residue fragments were tested, and the highest absolute value in each row is highlighted in bold; the higher absolute value for the diameter and bark thickness is underlined.

\begin{tabular}{|c|c|c|c|}
\hline & Tree part & Diameter & Bark thickness \\
\hline Tree part & 1.000 & $-0.921^{*}$ & $-0.772^{*}$ \\
\hline Diameter & $-0.921^{*}$ & 1.000 & $0.752^{*}$ \\
\hline Bark thickness & $0.772^{*}$ & $-0.752^{*}$ & 1.000 \\
\hline Acanthocinus griseus & 0.011 & $\underline{0.088^{*}}$ & 0.005 \\
\hline Arhopalus rusticus & $-0.133^{*}$ & $-\overline{0.008}$ & $\underline{0.100^{*}}$ \\
\hline Rhagium inquisitor & $-0.230^{*}$ & $0.088^{*}$ & $\underline{0.199^{*}}$ \\
\hline Pissodes pini & $-0.087^{*}$ & $\underline{0.166^{*}}$ & $0.138^{*}$ \\
\hline Crypturgus cinereus & 0.022 & $\underline{0.059^{*}}$ & $-0.041^{*}$ \\
\hline Hylastes opacus & 0.022 & $\underline{0.082^{*}}$ & 0.003 \\
\hline Hylurgops palliatus & $-0.171^{*}$ & $\underline{0.214^{*}}$ & $0.180^{*}$ \\
\hline Pityogenes chalcographus & $-0.032^{*}$ & 0.040 & -0.101 \\
\hline Pityophthorus pityographus & 0.025 & $-0.145^{*}$ & -0.057 \\
\hline Tomicus minor & -0.147 & 0.031 & $\underline{0.076^{*}}$ \\
\hline Tomicus piniperda & $-0.396^{*}$ & $0.330^{*}$ & $\underline{0.448^{*}}$ \\
\hline Trypodendron lineatum & $0.131^{*}$ & -0.023 & $\underline{0.083^{*}}$ \\
\hline
\end{tabular}

${ }^{*}$ Significant correlations $(P<0.05)$.

trees ( $R$. inquisitor, C. cinereus, H. opacus, $H$. palliatus, $T$. minor and $T$. lineatum). The trees felled in August were regularly colonised only by R. inquisitor, P. pini, H. opacus, $H$. palliatus and $T$. lineatum and occasionally by $T$. piniperda, whereas other species obviously avoided these trees. Hylastes opacus was the only species to exhibit the highest frequency of occurrence on the LR from August.

The gallery coverage of all species present on at least $100 \mathrm{LR}$ fragments (excluding P. pini and $T$. piniperda) were significantly affected by the post-felling cutting of the trees, with most species showing a significantly higher gallery coverage on the cut trees (Table 4, Fig. 3b). Furthermore, several species (A. griseus, $H$. opacus, $H$. palliatus, $P$. chalcographus and $T$. minor) exhibited significant differences in their gallery coverage between the upper and lower sides of the LR fragments (Table 4, Fig. 3c), with most of these species (excluding $P$. chalcographus) exhibiting a higher gallery coverage on the lower side. Species such as $R$. inquisitor, $H$. opacus and $H$. palliatus were significantly more abundant on LR fragments that were in substantial contact with the ground. In contrast, $A$. griseus and $T$. minor occurred in greater numbers on LR without or with negligible direct contact with the ground (Table 4, Fig. 3d).

\section{Discussion}

Logging residues from pre-commercial thinning offer more diverse habitats for the development of BWBB than LR from fellings in older stands, i.e. where trunks are removed. Accordingly, the number of species found in the present study (28) was considerably higher than that reported in studies performed on other types of Scots pine LR, such as pine stumps (8 species, England, Wallace (1953); 17 species, Czech Republic, Foit (2012a)) or pine branches and tops generated through thinning or main felling (16 and 25 species respectively, Czech Republic, Foit (2011)). Moreover, the number of recorded species was comparable to that found on whole standing mature Scots pine trees (17 species, Finland, Väisänen et al. (1993)); 23 species, Poland, Zabecki (1999); 34 species, Czech Republic, Foit (2007, 2010)). Although no red-listed BWBB species were observed, the high total number of species 
Table 4. Statistical significances of differences in the gallery coverage of particular species on logging residue (LR) fragments with various characteristics (felling date, post-felling cutting, orientation of the LR surface towards the ground and contact of the LR with the ground). The differences were tested using the Kruskal-Wallis test (felling date) or Mann-Whitney $U$ test (other variables). Only the species recorded on at least $100 \mathrm{LR}$ fragments were tested.

\begin{tabular}{|c|c|c|c|c|}
\hline & Felling date & $\begin{array}{l}\text { Post-felling } \\
\text { cutting } \\
\text { (whole/cut) }\end{array}$ & $\begin{array}{l}\text { Orientation of } \\
\text { LR surface } \\
\text { towards ground } \\
\text { (upper/lower side) }\end{array}$ & $\begin{array}{l}\text { Contact of LR } \\
\text { with ground } \\
\text { (air/ground)* }\end{array}$ \\
\hline & $\begin{array}{l}K W-H(3 ; 10,810) \\
P\end{array}$ & $\begin{array}{l}U(\mathrm{n} 1=\mathrm{n} 2=5,405) \\
P\end{array}$ & $\begin{array}{l}U(\mathrm{n} 1=\mathrm{n} 2=3,365) \\
P\end{array}$ & $\begin{array}{l}U(\mathrm{n} 1=\mathrm{n} 2=1,440) \\
P\end{array}$ \\
\hline \multirow[t]{2}{*}{ Acanthocinus griseus } & 41.0 & 1885078 & 736733 & 50832 \\
\hline & $<0.001$ & $<0.001$ & 0.025 & $<0.001$ \\
\hline \multirow[t]{2}{*}{ Arhopalus rusticus } & 68.7 & 1902946 & 745347 & 52126 \\
\hline & $<0.001$ & $<0.001$ & 0.490 & 0.677 \\
\hline \multirow[t]{2}{*}{ Rhagium inquisitor } & 55.4 & 1834488 & 736717 & 48076 \\
\hline & $<0.001$ & $<0.001$ & 0.660 & 0.004 \\
\hline \multirow{2}{*}{ Pissodes pini } & 69.3 & 1920676 & 736717 & 51137 \\
\hline & $<0.001$ & 0.556 & 0.121 & 0.351 \\
\hline \multirow[t]{2}{*}{ Crypturgus cinereus } & 86.3 & 1888563 & 745368 & 51969 \\
\hline & $<0.001$ & $<0.001$ & 0.621 & 0.164 \\
\hline \multirow[t]{2}{*}{ Hylastes opacus } & 15.1 & 1900966 & 738650 & 48124 \\
\hline & 0.002 & $<0.001$ & 0.023 & $<0.001$ \\
\hline \multirow[t]{2}{*}{ Hylurgops palliatus } & 105.4 & 1726878 & 721289 & 46178 \\
\hline & $<0.001$ & $<0.001$ & 0.003 & $<0.001$ \\
\hline \multirow[t]{2}{*}{ Pityogenes chalcographus } & 263.0 & 1841358 & 725769 & 51973 \\
\hline & $<0.001$ & $<0.001$ & 0.044 & 0.167 \\
\hline \multirow[t]{2}{*}{ Pityophthorus pityographus } & 90.6 & 1882568 & 745395 & - \\
\hline & $<0.001$ & $<0.001$ & 0.509 & - \\
\hline \multirow[t]{2}{*}{ Tomicus minor } & 321.1 & 1813523 & 692109 & 46042 \\
\hline & $<0.001$ & $<0.001$ & $<0.001$ & $<0.001$ \\
\hline \multirow[t]{2}{*}{ Tomicus piniperda } & 89.1 & 1926001 & 746744 & 50252 \\
\hline & $<0.001$ & 0.936 & 0.928 & 0.316 \\
\hline \multirow[t]{2}{*}{ Trypodendron lineatum } & 37.0 & 1894509 & 743618 & 51335 \\
\hline & $<0.001$ & $<0.001$ & 0.237 & 0.113 \\
\hline
\end{tabular}

${ }^{*}$ For LR in contact with the ground, only the data for the three basal sections of trunk were used (see Methods).

identified within the studied insect group suggests that the overall saproxylic insect assemblages associated with these LR might be notably species rich and conservationally valuable. Additionally, the recorded species comprised several pests (Gregoire \& Evans 2004), chiefly $P$. chalcographus, T. minor and T. piniperda. Because these species were the most frequent species recorded in the present study, it is clear that they can multiply on LR generated through precommercial thinning. The importance of LR for the multiplication of certain BWBB pests, including $P$. chalcographus and $T$. minor, has been previously documented in several studies (Six et al. 2002, Kula \& Kajfosz 2007, Kula et al. 2011, Foit 2012b, Kacprzyk 2012). In contrast, the observation of such extensive multiplication of $T$. piniperda, which requires thick bark for development (Schwenke 1972), on the relatively thin LR generated from the pre-commercial thinning of these young stands was unexpected. However, Långström and Hellqvist (1993) also recorded a heavy attack of baited 30-year old Scots pine trees by this species in central Sweden.

All of the studied habitat factors (tree part, diameter, bark thickness, felling date, post-felling cutting of the LR, orientation of the LR surface towards the ground, and contact of the LR with the ground) significantly affected the composition of the BWBB assemblages and were able to 
a)
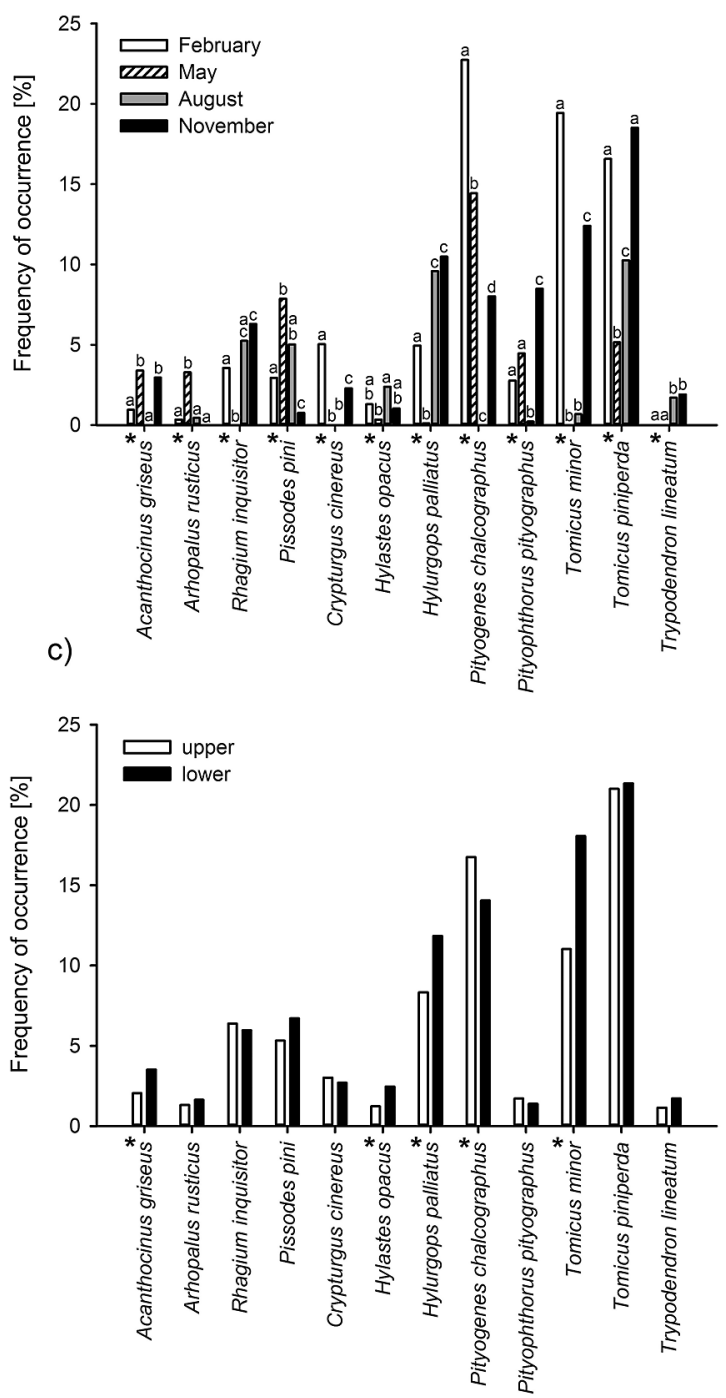

b)
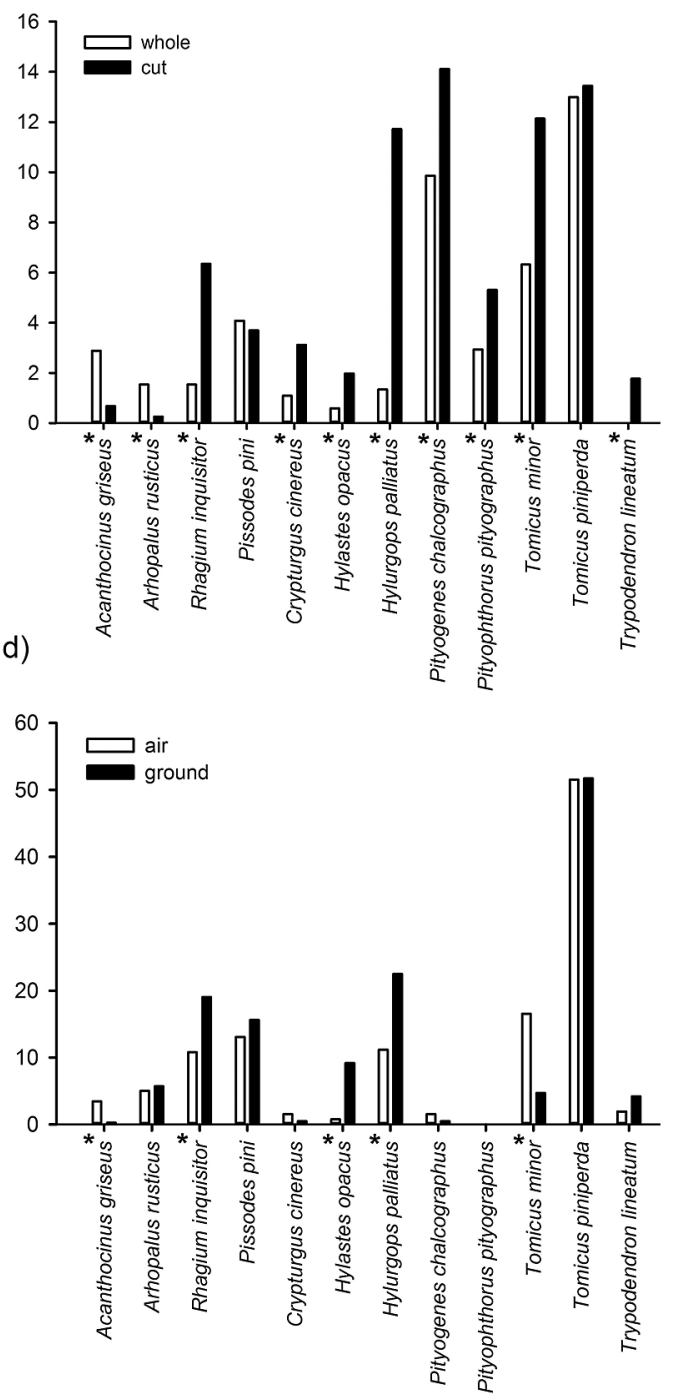

Fig. 3. Frequencies of occurrence of the recorded species with respect to: $-a$. Felling date. $-b$. Post-felling cutting. $-\mathrm{c}$. Orientation of the logging residue $(L R)$ surface towards the ground. $-d$. Contact of the $L R$ with the ground (only data on the three basal sections of trunk were included - see Methods). Different letters within species show significant differences, see Methods. An asterisk (*) indicates species showing significant differences in the gallery coverage (Table 4). Only the species recorded on at least $100 \mathrm{LR}$ fragments were included in the analyses.

explain a substantial portion $(16.6 \%)$ of the variability in the species' gallery coverage (Table 2), with tree part, diameter, bark thickness and felling date the most important factors. Some of these associations have been previously noted. For example, the part of the tree was found to be the most important factor affecting the species occurrence of BWBB on standing Scots pine trees (Foit
2010), and the effect of the substrate diameter and bark thickness on the occurrence of saproxylic beetles has been illustrated in several other studies (Zhang et al. 1993, Schiegg 2001, Lindhe \& Lindelöw 2004, Lindhe et al. 2005, Jonsell et al. 2007, Maňák 2007, Jonsell 2008, Foit 2010, Brin et al. 2011). Furthermore, the impact of the felling date was previously documented in studies on 
different types of Norway spruce (Picea abies (L.) Karst.) and Scots pine LR (Kula \& Kajfosz 2006, 2007, Foit 2012a, b).

The tree parts exhibited stronger explanatory power than did the metric variables (diameter and bark thickness) together (Table 2), which most likely reflected the strong correlations between bark thickness and diameter with the tree parts (Table 1,3). Indeed, the majority of the variance in these factors can be explained by the tree parts alone, and the tree parts may be more strongly correlated with certain unstudied variables (e.g., substrate humidity and anatomical and chemical constitution). Some species were significantly associated with certain tree parts (Fig. 2), and these associations more or less fit known substrate preferences (Schwenke 1972). Among the four species found to be more closely associated with the tree parts than with their metric variables (Table 3), a clear explanation was only found for A. rusticus because this species was mostly bound to the first basal trunk section (Fig. 2). However, the diameter explained a higher proportion of the variability in the species composition of assemblages (Table 2) and was the most important metric varible of tree parts for the gallery coverage of the six assessed species (Table 3), whereas bark thickness, which was only different on the basal part of the tree trunks (Table 1), exhibited similar explanatory power and was a more important variable than diameter in determining the gallery coverage of six species (Table 3). Accordingly, Foit (2010) documented bark thickness as the most important metric variable affecting the occurrence of BWBB on standing Scots pines. Not surprisingly, mostly species associated with the lower part of the trunk, with thick bark (A. rusticus, $R$. inquisitor, T. piniperda and $T$. lineatum), showed stronger association with bark thickness than with diameter in the present study (Table 3, Fig. 2). In contrast, $P$. chalcographus, which exhibited the strongest association with bark thickness, could colonise almost every part of the felled trees covered by thin bark regardless of diameter (in most cases). The diameter of the tree parts was the most important variable for several species associated primarily with the middle (A. griseus and $C$. cinereus) to lower (P. pini, H. opacus and H. palliatus) part of the trunk. These species most likely avoided sub- strates that were too thin and had a tolerance for various bark thicknesses (Escherich 1923, Schwenke 1972, Bense 1995, Sauvard 2004). In contrast, $P$. pityographus (also associated mostly with diameter) evidently preferred thin substrates on branches and extreme tree tops (Fig. 2), where the thickness of the almost uniformly thin bark (Table 1) may not have played a significant role.

The substantial impact of the month of felling (Table 2, 4, Fig. 3a) was most likely associated with the timing of the species' mating/egg laying, and with requirements of particular species for the stage of substrate dieback/decay. As the majority of the recorded species exhibit spring-toearly summer mating/egg-laying periods (Schwenke 1972), the trees felled in August were not colonised in the year of felling and remained attractive only to secondary species ( $R$. inquisitor, $P$. pini, H. opacus, $H$. palliatus, $T$. lineatum and occasionally $T$. piniperda) (Escherich 1923, Schwenke 1972, Gregoire \& Evans 2004, Wermelinger et al. 2008, Foit 2014) in the following year. In contrast, the LR produced in the winter were densely colonised by the most aggressive recorded species ( $P$. chalcographus and T. minor) (Escherich 1923, Schwenke 1972, Gregoire \& Evans 2004, Wermelinger et al. 2008, Foit 2014) early after felling. Trees felled in May were frequently used as a breeding substrate, predominately by species with later mating/egg-laying periods ( $A$. griseus, $A$. rusticus, $P$. pini) (Schwenke 1972), whereas species exhibiting earlier egg laying notably avoided such trees (T. minor, T. piniperda and T. lineatum). Logging residues produced in November did not show distinct patterns of colonisation by any particular species, as these residues entered the vegetative period in an overly degraded state to be attractive to typical secondary species ( $R$. inquisitor, $H$. palliatus and $T$. lineatum), but were still sufficiently fresh to attract some of the more aggressive species ( $P$. chalcographus, T. minor and $T$. piniperda). These findings correspond to results of other studies in which $P$. chalcographus was documented to avoid LR from summer fellings and to be most frequently found on LR from the winter and spring (Kula \& Kajfosz 2007, Foit 2012b). Despite the slightly later egg-laying period of C. cinereus (Schwenke 1972), this species showed almost the same pattern of occurrence on 
LR from particular months as $T$. minor, which might have been caused by the association of $C$. cinereus with the latter species as determined by the Spearman correlation index after removing the effects of the tree identity, tree part, diameter and bark thickness by fitting the GLM and extracting the residuals: $\mathrm{s}=0.191, P<0.05$. Crypturgus cinereus is known to use the entrance holes of other scolytids for access to areas under the bark of trees (Pfeffer 1955, Schwenke 1972) and was found to mainly exploit $T$. minor entrance holes for this purpose in the present study.

The post-felling cutting of the trees showed only a weak effect on the overall species composition of the BWBB assemblages (Table 2). This effect was not decreased by the addition of other habitat covariables in the calculation, and remarkable effects on the occurrence of particular species were found (Table 4, Fig. 3b). Species associated with the basal part of the trunk (i.e., $R$. inquisitor, H. opacus, H. palliatus and T. lineatum) that prefer a substrate with sufficient humidity (Pfeffer 1955, Schwenke 1972) and are attracted to ethanol (a product of ongoing substrate degradation/fermentation, Schroeder \& Lindelöw 1989, Byers 1992, Sweeney et al. 2007) preferred cut trees in the present study. This suggests that the loss of water from the basal parts of trunks with no living branches was slowed by the disruption of water-conducting tissues (in the case of cut trees), thereby enabling the subsequent fermentation of tissues. In contrast, several of the first-colonising species associated with the upper parts of trees were also significantly more abundant on cut trees (C. cinereus, $T$. minor, $P$. chalcographus and $P$. pityographus), which could have been due to the higher levels of attractive volatiles emitted from cut trees. Only A. griseus and $A$. rusticus (both late mating/egg-laying species (VI-VIII)) (Schwenke 1972) were found to be more abundant on uncut trees, which could simply be the result of stronger competition with earlier egg-laying species on cut trees.

However, the effects of the LR surface orientation towards the ground and contact of the LR with the ground on the overall species composition of the BWBB assemblages were almost negligible (Table 2), although several species were significantly affected by these variables (Table 4, Fig. 3c, d). Pityogenes chalcographus was signif- icantly more abundant on the upper side of LR, most likely due to its requirements for higher temperatures, as this species has been shown to prefer sunny clear-cut areas (Peltonen \& Heliövaara 1999, Johansson et al. 2006) and to be most abundant in the top layer of LR piles (Kacprzyk 2012). In contrast, the higher gallery coverage of T. minor on the lower side of LR might be related to its strong association with mutualistic fungi (Ophiostoma canum (Münch) Syd. \& P. Syd. and Ambrosiella tingens (Lagerb. \& Melin) L.R. Batra) (Kirisits 2004, Jankowiak 2008) requiring a certain level of humidity. The documented preference of $R$. inquisitor, $H$. opacus and $H$. palliatus for fragments of LR showing substantial contact with the ground and higher gallery coverage of $H$. opacus and $H$. palliatus on the lower sides of the LR most likely reflected the species' requirements for higher humidity (Pfeffer 1955, Peltonen \& Heliövaara 1999). In contrast, the association of $A$. griseus and T. minor with LR that did not have significant contact with the ground was not easily explained, although it might have been related to the species avoiding high humidity.

\section{Conclusions and implications for forest management}

Leaving trees in a stand that have been felled during pre-commercial thinning provides substrates for the development of a substantial number of BWBB species and most likely supports a number of other saproxylic species. The occurrence of different species and, thus, the overall composition of the assemblages differs significantly among various tree parts and is strongly affected by substrate diameter, bark thickness and the date of felling and, to a lesser extent, by the post-felling cutting of trees into $1 \mathrm{~m}$ sections, the contact of the LR with the ground and the orientation of the LR surface towards the ground (upper/lower side).

In contrast, it has been documented that LR generated from pre-commercial thinning can enable the multiplication of a number of pests, such as $P$. chalcographus, $T$. minor and $T$. piniperda. The occurrence of all these species is significantly affected by the felling date, and based on 
the results of the present study, we can infer that the risk of their multiplication can be minimised if fellings are conducted between July and September. Furthermore, leaving whole trees in a stand, without cutting them into smaller parts, should reduce the multiplication of certain pests ( $P$. chalcographus, T. minor and $P$. pityographus).

Acknowledgements. This study was supported by the European Social Fund and the state budget of the Czech Republic, Project No. CZ.1.07/2.3.00/30.0017. I appreciate the assistance of I. Březina with the experimental fellings.

\section{References}

Abrahamsson, M., Lindbladh, M. \& Ronnberg, J. 2008: Influence of butt rot on beetle diversity in artificially created high-stumps of Norway spruce. - Forest Ecology and Management 255: 3396-3403.

Bense, U. 1995: Longhorn beetles: illustrated key to the Cerambycidae and Vesperidae of Europe. - Margraf Verlag, Weikersheim. 512 pp.

Bílý, S. 1989: Krascovití (Buprestidae) (Buprestid beetles). - Academia, Praha. 111 pp. [In Czech.]

Braun-Blanquet, J. 1964: Pflanzensoziologie : Grundzüge der Vegetationskunde. — Springer-Verlag, Wien, New York. 865 pp. [In German.]

Brin, A., Bouget, C., Brustel, H. \& Jactel, H. 2011: Diameter of downed woody debris does matter for saproxylic beetle assemblages in temperate oak and pine forests. - Journal of Insect Conservation 15: 653-669.

Byers, J. A. 1992: Attraction of bark beetles, Tomicus piniperda, Hylurgops palliatus, and Trypodendron domesticum and other insects to short-chain alcohols and monoterpenes. - Journal of Chemical Ecology 18: 2385-2402.

DeGomez, T., Fettig, C. J., McMillin, J. D., Anhold, J. A. \& Hayes, C. 2008: Managing slash to minimize colonization of residual leave trees by Ips and other bark beetle species following thinning in southwestern ponderosa pine. - University of Arizona, College of Agriculture and Life Sciences, Tucson, Arizona. 12 pp.

Dobson, A. J. \& Barnett, A. G. 2008: An introduction to generalized linear models, $3^{\text {rd }}$ edition. - Chapman \& Hall/CRC, Boca Raton. 320 pp.

Escherich, K. 1923: Die Forstinsekten Mitteleuropas : ein Lehr- und Handbuch. — Paul Parey, Berlin. 663 pp. [In German.]

Foit, J. 2007: The fauna of cambioxylophagous insects on Scots pine trees declined after spells of drought in 2003. - Journal of Forest Science 53: 334-339.

Foit, J. 2010: Distribution of early-arriving saproxylic beetles on standing dead Scots pine trees. - Agricultural and Forest Entomology 12: 133-141.

Foit, J. 2011: Kambioxylofágní hmyz na borovici lesní-se zvláštním přihlédnutím $\mathrm{k}$ jeho vývoji na těžebním odpadu (Cambioxylophagous insects on the Scots pine trees with special focus on the insects' development on logging residues). [Ph.D. Thesis]. - Mendel University in Brno, Brno. 182 pp. [In Czech, summary in English.]

Foit, J. 2012a: Early-arriving saproxylic beetles developing in Scots pine stumps: effects of felling type and date. - Journal of Forest Science 58: 503-512.

Foit, J. 2012b: Felling date affects the occurrence of Pityogenes chalcographus on Scots pine logging residues. - Agricultural and Forest Entomology 14: 383-388.

Foit, J. 2014: Colonization of disturbed Scots pine trees by barkand wood-boring beetles. - Agricultural and Forest Entomology 16: 184-195.

Gregoire, J. C. \& Evans, H. F. 2004: Damage and control of BAWBILT organisms an overview. - In: Lieutier, F., Day, K. R., Battisti, A., Gregoire, J.-C. and Evans, H. F. (eds), Bark and wood boring insects in living trees in Europe: a synthesis.: 19-37. Kluwer Academic Publishers, Dordrecht, Boston \& London. 569 pp.

Hedgren, P. O., Weslien, J. \& Schroeder, L. M. 2003: Risk of attack by the bark beetle Pityogenes chalcographus (L.) on living trees close to colonized felled spruce trees. - Scandinavian Journal of Forest Research 18: $39-44$.

Hollander, M. \& Wolfe, D. A. 1999: Nonparametric statistical methods, $2^{\text {nd }}$ edition. - Wiley, New York. 816 pp.

Jankowiak, R. 2008: Fungi associated with Tomicus minor on Pinus sylvestris in Poland and their succession into the sapwood of beetle-infested windblown trees. Canadian Journal of Forest Research-Revue Canadienne De Recherche Forestiere 38: 2579-2588.

Johansson, T., Gibb, H., Hilszczański, J., Hjältén, J., Atlegrim, O., Ball, J. P. \& Danell, K. 2006: Conservation-oriented manipulations of coarse woody debris affect its value as habitat for spruce-infesting bark and ambrosia beetles (Coleoptera : Scolytinae) in northern Sweden. - Canadian Journal of Forest Research-Revue Canadienne De Recherche Forestiere 36: 174 185.

Jonsell, M. 2008: Saproxylic beetle species in logging residues: which are they and which residues do they use? Norwegian Journal of Entomology 55: 109-122.

Jonsell, M., Hansson, J. \& Wedmo, L. 2007: Diversity of saproxylic beetle species in logging residues in Sweden - Comparisons between tree species and diameters. - Biological Conservation 138: 89-99.

Jonsell, M., Nitterus, K. \& Stighall, K. 2004: Saproxylic beetles in natural and man-made deciduous high stumps retained for conservation. - Biological Conservation 118: 163-173.

Jonsell, M., Schroeder, M. \& Weslien, J. 2005: Saproxylic beetles in high stumps of spruce: Fungal flora important for determining the species composition. - Scandinavian Journal of Forest Research 20: 54-62.

Jonsell, M. \& Weslien, J. 2003: Felled or standing retained wood - it makes a difference for saproxylic beetles. Forest Ecology and Management 175: 425-435. 
Kacprzyk, M. 2012: Feeding habits of Pityogenes chalcographus (L.) (Coleoptera: Scolytinae) on Norway Spruce (Picea abies) L. (Karst.) logging residues in wind-damaged stands in southern Poland. - International Journal of Pest Management 58: 121-130.

Kaila, L., Martikainen, P. \& Punttila, P. 1997: Dead trees left in clear-cuts benefit saproxylic Coleoptera adapted to natural disturbances in boreal forest. - Biodiversity and Conservation 6:1-18.

Kirisits, T. 2004: Fungal associates of European bark beetles with special emphasis on the ophiostomatoid fungi. - In: Lieutier, F., Day, K. R., Battisti, A., Gregoire, J.C. and Evans, H. F. (eds), Bark and wood boring insects in living trees in Europe: a synthesis.: 181-235. Kluwer Academic Publishers, Dordrecht, Boston \& London. 569 pp.

Kula, E. \& Kajfosz, R. 2006: Osídlování smrkového těžebního odpadu z jarní prořezávky kambioxylofágy ve vyšších nadmořských výškách Beskyd (Colonization of spruce logging debris from spring cleaning by cambioxylophagous insect at higher locations of the Beskids). - The Beskids Bulletin 19: 171-176. [In Czech, abstract in English.]

Kula, E. \& Kajfosz, R. 2007: Colonization of spruce logging debris from summer and autumn cleaning by cambioxylophagous insect at higher locations of the Beskids. - The Beskids Bulletin 20: 193-198.

Kula, E., Kajfosz, R. \& Polívka, J. 2011: Cambioxylophagous fauna developing on logging residues of blue spruce (Picea pungens Engelmann). - Journal of Forest Science 57: 24-33.

Långström, B. \& Hellqvist, C. 1993: Induced and spontaneous attacks by pine shoot beetles on young Scots pine trees - tree mortality and beetle performance. Journal of Applied Entomology 115: 25-36.

Larkin, P. A. \& Elbourn, C. A. 1964: Some observations on fauna of dead wood in live oak trees. - Oikos 15: 79-92.

Lassauce, A., Lieutier, F. \& Bouget, C. 2012: Woodfuel harvesting and biodiversity conservation in temperate forests: Effects of logging residue characteristics on saproxylic beetle assemblages. - Biological Conservation 147: 204-212.

Lindhe, A. \& Lindelöw, Å. 2004: Cut high stumps of spruce, birch, aspen and oak as breeding substrates for saproxylic beetles. - Forest Ecology and Management 203: 1-20.

Lindhe, A., Lindelöw, Å. \& Asenblad, N. 2005: Saproxylic beetles in standing dead wood density in relation to substrate sun-exposure and diameter. - Biodiversity and Conservation 14: 3033-3053.

Maňák, V. 2007: Saproxylic beetles in two types of fine woody debris of Norway spruce. [Master Thesis]. Swedish University of Agricultural Sciences, Uppsala. $16 \mathrm{pp}$.

Manly, B. F. J. 2001: Randomization and Monte Carlo methods in biology. - Chapman \& Hall, London. 281 pp.

McGeoch, M. A., Schroeder, M., Ekbom, B. \& Larsson, S. 2007: Saproxylic beetle diversity in a managed boreal forest: importance of stand characteristics and forestry conservation measures. - Diversity and Distributions 13: 418-429.

Peltonen, M. \& Heliövaara, K. 1999: Attack density and breeding success of bark beetles (Coleoptera, Scolytidae) at different distances from forest-clearcut edge. - Agricultural and Forest Entomology 1: 237-242.

Pfeffer, A. 1955: Kůrovci (Coleoptera: Scolytidae) (Scolytid beetles (Coleoptera: Scolytidae)). — Nakladatelství Československé Akademie Věd, Praha. 324 pp. [In Czech.]

Pfeffer, A. 1995: Zentral- und Westpalaarktische Borkenund Kernkafer (Coleoptera, Scolytidae, Platypodidae). - Pro Entomologia, Naturhistorisches Musem Basel, Basel. 310 pp. [In German.]

Sauvard, D. 2004: General biology of bark beetles. - In: Lieutier, F., Day, K. R., Battisti, A., Gregoire, J.-C. and Evans, H. F. (eds), Bark and wood boring insects in living trees in Europe: a synthesis: 63-88. Kluwer Academic Publishers, Dordrecht, Boston \& London. $569 \mathrm{pp}$.

Schiegg, K. 2000: Effects of dead wood volume and connectivity on saproxylic insect species diversity. Ecoscience 7: 290-298.

Schiegg, K. 2001: Saproxylic insect diversity of beech: limbs are richer than trunks. - Forest Ecology and Management 149: 295-304.

Schroeder, L. M. \& Lindelöw, A. 1989: Attraction of scolytids and associated beetles by different absolute amounts and proportions of alpha-pinene and ethanol. - Journal of Chemical Ecology 15: 807-817.

Schwenke, W. 1972: Die Forstschädlinge Europas, 2.Band. - Parey, Hamburg. 500 pp. [In German.]

Siitonen, J. 2001: Forest management, coarse woody debris and saproxylic organisms: Fennoscandian boreal forests as an example. - Ecological Bulletins 49: 11 41.

Similä, M., Kouki, J. \& Martikainen, P. 2003: Saproxylic beetles in managed and seminatural Scots pine forests: Quality of dead wood matters. - Forest Ecology and Management 174: 365-381.

Six, D. L., Vander Meer, M., DeLuca, T. H. \& Kolb, P. 2002: Pine engraver (Ips pini) colonization of logging residues created using alternative slash management systems in Western Montana. - Western Journal of Applied Forestry 17: 96-100.

StatSoft, I. 2013: Electronic statistics textbook. OK: StatSoft, Tulsa. [www document]. URL http:/www.statsoft.com/textbook/. (Site visited on 30 September, 2014).

Sverdrup-Thygeson, A. \& Ims, R. A. 2002: The effect of forest clearcutting in Norway on the community of saproxylic beetles on aspen. - Biological Conservation 108: 377-378.

Švácha, P. \& Danilevsky, M. L. 1986: Cerambycoid larvae of Europe and Soviet Union (Coleoptera : Cerambycoidea), Part I. - Acta Universitatis Carolinae - Biologica 30: 1-176.

Švácha, P. \& Danilevsky, M. L. 1987: Cerambycoid larvae of Europe and Soviet Union (Coleoptera : Ceramby- 
coidea), Part II. - Acta Universitatis Carolinae - Biologica 31: 1-284.

Švácha, P.\& Danilevsky, M. L. 1988: Cerambycoid larvae of Europe and Soviet Union (Coleoptera : Cerambycoidea), Part III. - Acta Universitatis Carolinae Biologica 32: 1-205.

Sweeney, J., de Groot, P., Humble, L., MacDonald, L., Price, J., Mokrzycki, T. \& Gutowski, J. M. 2007: Detection of wood-boring species in semiochemical-baited traps. - In: Evans, H. and Oszak, T. (eds), Alien Invasive Species and International Trade: 139-144. Forest Research Institute, Poland. 179 pp.

ter Braak, C. J. F. 1986: Canonical correspondence-analysis - a new eigenvector technique for multivariate direct gradient analysis. - Ecology 67: 1167-1179.

ter Braak, C. J. F. 1987: A fortran program for community ordination by (partial) (detrended) (canonical) correspondence analysis, principal components analysis and redundancy analysis (version 2.1). - Agricultural Mathematics Group, Wageningen. 95 pp.

Väisänen, R., Biström, O. \& Heliövaara, K. 1993: Subcortical Coleoptera in dead pines and spruces - is primeval species composition maintained in managed forests? - Biodiversity and Conservation 2: 95-113.

Vanderwel, M. C., Malcolm, J. R., Smith, S. A. \& Islam, N. 2006: Insect community composition and trophic guild structure in decaying logs from eastern Canadian pine-dominated forests. - Forest Ecology and Management 225: 190-199.

Victorsson, J. \& Jonsell, M. 2013: Effects of stump extraction on saproxylic beetle diversity in Swedish clearcuts. - Insect Conservation and Diversity 6: 483 493.
Wallace, H. R. 1953: The ecology of the insect fauna of pine stumps. - Journal of Animal Ecology 22: 154 171.

Wermelinger, B., Rigling, A., Mathis, D. S. \& Dobbertin, M. 2008: Assessing the role of bark- and wood-boring insects in the decline of Scots pine (Pinus sylvestris) in the Swiss Rhone valley. - Ecological Entomology 33: 239-249.

Weslien, J., Djupström, L. B., Schroeder, M. \& Widenfalk, O. 2011: Long-term priority effects among insects and fungi colonizing decaying wood. - Journal of Animal Ecology 80: 1155-1162.

Zabecki, D. T. 1999: Podatność drzewostanów sosnowych na zasiedlanie przez owady kambio- i ksylofagiczne w rejonie Tarnobrzkiego Zagłębia Siarkowego (Susceptibility of pine stands to infestation by cambio- and xylophagous insects in the area of the Tarnobrzek Sulphur Basin). - Zeszyty Naukowe Akademii Rolniczej Im. H. Kołłataja w Krakowe, Rozprawy 254: 1-98. [In Polish.]

Zabecki, W. \& Kacprzyk, M. 2007: A potentiality of using spruce branches left in the forest after incidental cuttings to attract Pityogenes chalcographus (L.). - The Beskids Bulletin 20: 185-192.

Zhang, Q. H., Byers, J. A. \& Zhang, X. D. 1993: Influence of bark thickness, trunk diameter and height on reproduction of the longhorned beetle, Monochamus sutor (Col, Cerambycidae) in burned larch and pine. Journal of Applied Entomology-Zeitschrift Fur Angewandte Entomologie 115: 145-154. 